\title{
BANK DESA SEBAGAI INOVASI EKONOMI PEMBANGUNAN BERKELANJUTAN MELALUI STRATEGI KEMITRAAN DAN TATA KELOLA PEMERINTAHAN
}

\section{VILLAGE BANK AS A SUSTAINABLE DEVELOPMENT ECONOMIC DEVELOPMENT THROUGH A PARTNERSHIP STRATEGY AND GOVERNANCE MANAGEMENT}

\author{
Mawar Sukma Sinaga ${ }^{1}$ dan Wahyu² \\ 1)Universitas Maritim Raja Ali Haji - Tanjungpinang \\ 2)Universitas Maritim Raja Ali Haji - Tanjungpinang \\ Email : mawamoela@gmail.com
}

\begin{abstract}
ABSTRAK
Tujuan penelitian ini adalah untuk meneliti dan menganalisis bank desa sebagai inovasi ekonomi pembangunan berkelanjutan melalui strategi kemitraan dan tata kelola pemerintahan dengan collaborative governance. Adapun penelitian berjenis deskriptif ini untuk memuat gambaran atau lukisan secara sistematik, faktual dan akurat mengenai fakta-fakta, sifat-sifat serta hubungan antar fenomena yang diselidiki. Penelitian ini bersumber dari data primer melalui studi pustaka. Hasil penelitian ini mengungkapkan Bank Desa dapat dijadikan alternatif dikalangan masyarakat desa yang banyak terjerat rentenir, kurangnya masyarakat desa mendapat bantuan ketika sulit, sulitnya mencari modal ketika akan memulai usaha maupun memperbesar usaha. Perlu diketahui juga kalau desa saat ini sudah menjadi pasar, perputaran uang yang luar biasa juga terjadi didesa karena menjadi arena perdagangan. Karena itu harus mulai digerakan dan disiapkan peraturan untuk menjalankan Bank Desa. Keberadaan Badan Usaha Milik Desa (BUMDes) diharapkan juga mampu menstimulasi dan menggerakkan roda perekonomian di pedesaan.
\end{abstract}

Kata Kunci: Bank desa, Kolaboratif, inovasi ekonomi pembangunan

\begin{abstract}
The purpose of this study is to discuss and analyze village banks that support economic development through partnership and governance strategies with collaborative governance. Research facts regarding facts, facts, facts and facts between the facts investigated. This research sourced from primary data through literature study. The results of this study reveal the Village Bank can make an alternative among the village communities who are most entangled with moneylenders, villages that are eligible for compilation assistance, the difficulty of finding compilation capital will start a business by adding a business. It is also necessary if the village has now become a market, extraordinary turnover of money also occurs in the village because it becomes a trading arena. Because it must start to be moved and made regulations to run the Village Bank. Village-owned enterprises (BUMDes) are also expected to be able to stimulate and move the financial wheel in rural areas.
\end{abstract}

Keywords: Village bank, Collaborative, economic development innovation 


\section{PENDAHULUAN}

Mencapai tujuan pembangunan nasional, desa merupakan agen pemerintah terdepan yang dapat menjangkau kelompok sasaran riil yang hendak disejahterakan, yaitu dengan membentuk suatu badan usaha yaitu Badan Usaha Milik Desa (BUMDes) yang sesuai dengan Peraturan Menteri Desa, Pembangunan Daerah Tertinggal dan Transmigrasi Nomor 4 Tahun 2015 tentang Pendirian, Pengurusan, dan Pengelolaan, dan Pembubaran Badan Usaha Milik Desa (BUMDes), yang menyebutkan bahwa: "Pendirian Badan Usaha Milik Desa (BUMDes) yang dimaksudkan sebagai upaya menampung seluruh kegiatan di bidang ekonomi dan/atau pelayanan umum yang dikelola oleh desa dan/atau kerjasama antar desa.

Pembentukan ini berasal dari pemerintah kabupaten/kota dengan menetapkan peraturan daerah tentang pedoman tata cara pembentukandan pengelolaan BUMdes. Selanjutnya pemerintah desa membentuk BUMdes dengan peraturan desa yang berpedoman pada peraturan daerah. Peraturan daerah tersebut akan muncul dengan adanya Undang-Undang Nomor 23 Tahun 2014 perubahan atas Undang-Undang nomor 32 Tahun 2004 tentang Pemerintahan Daerah yang menyebutkan bahwa: "Dalam rangka mewujudkan amanat Undang-Undang Dasar Negara Republik Indonesia Tahun 1945, penyelenggaraan pemerintahan daerah diarahkan agar mampu melahirkan ke-pemimpinan daerah yang efektif dengan memperhatikan prinsip demokrasi, persamaan, keadilan, dan kepastian hukum dalam sistem Negara Kesatuan Republik Indonesia.

Keberadaan Pemerintah Daerah, khususnya Pemerintah Desa baik sebagai lembaga pemerintahan maupun sebagai entitas kesatuan masyarakat hukum adat menjadi sangat penting dan strategis. Sebagai lembaga pemerintahan, desa merupakan ujung tombak pemberian layanan kepada masyarakat. Sedangkan sebagai entitas kesatuan masyarakat hukum, desa merupakan basis system kemasyarakatan di desa yang sangat kokoh sehingga dapat menjadi landasan yang kuat bagi pengembangan sistem sosial ekonomi yang stabil dan dinamis. Sehingga desa merupakan miniature dan sample yang sangat baik untuk mengamati secara seksama interaksi antara pemerintah dengan masyarakatnya. Dan melalui desa inilah badan usaha milik desa dapat diselenggarakan dengan mengacu pada peraturan desa yang didasarkan pada peraturan daerah.

BUMDes diharapkan mampu menstimulasi dan menggerakkan roda perekonomian di pedesaan. Aset ekonomi yang ada di desa harus dikelola sepenuhnya oleh masyarakat desa. Substansi dan filosofi BUMDes harus dijiwai dengan semangat kebersamaan dan self help sebagai upaya memperkuat aspek ekonomi kelembagaannya. Akan tetapi masih terdapat kendala dari BUMDes seperti masalah sumber daya manusia dalam keuangan, tingkat kompetensi, lingkup organisasi BUMDes yang masih kecil sehingga memerlukan inovasi konsep lembaga keuangan mikro.

Berbicara tentang keuangan mikro, sebagai suatu kegiatan, dapat didefinisikan sebagai persediaan jasa keuangan untuk populasi berpenghasilan rendah, yang biasanya demikian tidak memiliki akses ke layanan ini melalui sistem keuangan tradisional. Kurangnya akses pelayana

berbankan umumnya dipandang sebagai salah satu alasan utama mengapa banyak orang di desa rata-rata terkategori masyarakat menengah bawah. Sebagaimana menurut data yang dikeluarkan oleh World Meters "Population of Indonesia", 2017 menyebutkan bahwa,jumlah penduduk Indonesia pada tahun 2017 yang mencapai 264.915.905 jiwa. Data dari Badan Pusat Statistik (BPS), 2018 menyebutkan bahwa dari jumlah tersebut,penduduk miskin di Indonesia mencapai 20.946,38 jiwa. Pemerintah Indonesia melalui Perpres Nomor 18 tahun 2007 telah 
merumuskan sasaran pembangunan ekonomi tahunan Indonesia diarahkan untuk mendorong pertumbuhan ekonomi dalam rangka memperluas lapangan pekerjaan dan mengurangi tingkat kemiskinan (Fathurrahman, 2012). Hal ini memang sudah menjadi kewajiban pemerintah,suatu negara dikatakan berhasil dalam pembangunan jika ia mampu menekan angka kemiskinan. Taraf kesejahteraan suatu negara akan berpengaruh di kancah internasional. Oleh karena itu, mengatasi masalah kemiskinan merupakan tantangan yang dihadapi oleh setiap negara. Tingkat kemiskinan di suatu negara akan mempengaruhi apakah negara tersebut termasuk negara maju, berkembang ataukah miskin. Dengan kata lain, tingkat kesejahteraan suatu negara dipengaruhi oleh besarnya prosentase kemiskinan di negara tersebut. Kondisi inilah yang memotivasi bersaing meningkatkan kesejahteraan termasuk Indonesia (Purbasari, 2013).

Namun, penyediaan layanan keuangan yang sesuai untuk usaha mikro dalam kelompok berpenghasilan rendah memiliki efek potensial positif pada ekonomi dan kondisi sosial di desa yang mengadopsi ini. Konsep yang akan peneliti tawarkan adalah Bank Desa yang berfondasi dari pelaksanaan BUMDes. Dengan kehadiran inovasi Bank Desa ditengah tengah jantung pangsa pasar dari sebuah desa ini diharapkan dapat mempermudah Nasabah dalam melakukan Transaksi sehingga dapat memaksimalkan penjualan segala penghasilan desa yang dibawa masyarakat dari semua pelosok desa yang bertransaksi di Bank Desa.

Menurut konsep Bank Desa yaitu: "Firstly, village banks have small scale of operation and simple form of organizations. Village banks are founded in rural areas, therefore, village banks serve for farmers in rural areas, where there are fewer branches, thus business decisions can be made more rapidly. Village banks are founded in different areas, thus management models are different. We mainly summarized three typical management models, taking Sichuan Yilong Huimin Village Bank, Jilin Zhenlai Guokai Village Bank and Dazu HSBC Village Bank for examples, then provided some references for village banks." (Shuang, Wang;Wang, Ji, Heng;Li \& Yu, 2015)

Pertama, bank desa memiliki skala operasi kecil dan bentuk organisasi yang sederhana. Bank desa adalah didirikan di daerah pedesaan, oleh karena itu, bank desa melayani untuk penghasilan (sektor pertanian atau kelautan) di daerah pedesaan, dimana jumlahnya lebih sedikit cabang, sehingga keputusan bisnis dapat dibuat lebih banyak dengan cepat. Kedua, Bank Desa memiliki kelemahan. Bank Desa terutama berfokus pada kelompok individu rumah tangga, usaha kecil dan menengah dan orang berpenghasilan rendah. Menurut fitur pelanggan, bank desa akan menyediakan berbagai jenis layanan untuk memenuhi permintaan pelanggan mereka dan memanfaatkan sepenuhnya keuntungan informasi, secara efektif menghindari masalah informasi yang tidak pantas dalam pembiayaan proses.

Ketiga, dana Bank Desa terbatas daerah pedesaan. Perbedaan antara Bank Desa dan bank komersial adalah bahwa bank desa mengambil simpanan, yang akan diinvestasikan di area yang mereka layani. Ini adalah sebuah cara yang baik untuk melayani pembangunan ekonomi lokal dan mencegah aliran dana. Namun demikian, bank komersial mengambil simpanan penduduk dan berinvestasi di daerah maju, sampai batas tertentu, mengabaikan pengembangan ekonomi pedesaan. Berdasarkan permasalahan dan debat teoritis diatas oleh karena itu peneliti mengambil judul yaitu Bank Desa sebagai Inovasi Pembangunan Ekonomi Berkelanjutan Melalui Strategi Kemitraan dan Tata Kelola Pemerintahan (Collaborative Governance).

Berdasarkan latar belakang yang telah diuraikan di atas, maka dapat ditarik suatu rumusan masalah yang akan menjadi fokus pembahasan dalam tulisan ini, yaitu: 1) Bagaimana pelaksanaan Bank Desa untuk menciptakan Ekonomi Pembangunan Berkelanjutan, 2) 
Bagaimana strategi yang digunakan dalam mengimplementasikan Bank Desa untuk menciptakan ekonomi pembangunan. Berdasarkan rumusan masalah yang telah diuraikan di atas, maka dapat ditarik tujuan penelitian yaitu: 1) Menjelaskan pelaksanaan Bank Desa untuk menciptakan Ekonomi Pembangunan yang berkelanjutan, 2) Menganalisis strategi yang tepat untuk digunakan dalam mengimplementasikan Bank Desa untuk menciptakan ekonomi pembangunan.

Manfaat yang diharapkan dalam penelitian ini, yakni a). Manfaat Praktis, Bagi stakeholder terutama pemerintah daerah setempat dan pengembang (developer), hasil tulisan ini diharapkan menjadi bahan evaluasi yang mampu memberikan kritikan dan masukan yang berguna dalam pengambilan kebijakan dalam mengatasi kemiskinan di daerah pedesaan. Bagi masyarakat, hasil penulisan ini diharapkan menjadi bahan informasi yang bisa diaplikasikan dan menjadi solusi yang tepat dalam peningkatan ekonomi pembangunan dipedesaan. Manfaat Teoritis Memberikan manfaat dalam pengembangan ilmu administrasi negara, khususnya dalam mengurai dan mencari kebenaran teori ekonomi pembangunan, partisipative comunication dan collaborative governance beserta praktiknya baik itu di pemerintahan, swasta, masyarakat beserta akademisi.

\section{LANDASAN TEORI}

\section{Teori Pembangunan Dam Ekonomi Pembangunan}

Pembangunan dalam pengertian ekonomi murni menunjukkan taraf kemampuan ekonomi nasional suatu negara untuk beranjak dari tahap awal yang relatif statis menuju peningkatan tahunan secara konsisten dan disertai perubahan struktural dibidang agraria, industri dan jasa, produksi dan lapangan kerja. Dengan tujuan pembangunan adalah meningkatkan kesejahteraan masyarakat yang ditandai dengan meningkatnya pendapatan dan menurunnya jumlah penduduk miskin. Amartya Sen (1999) menganggap GDP bukan merupakan tujuan utama pembangunan, tetapi memberikan makna pembangunan lebih luas yaitu kebebasan (freedom), kebebasan untuk memenuhi kebutuhan akan barang dan pekerjaan, kebebasan memilih dan menentukan kehidupannya (make choices and influence one"s life), termasuk kebebasan untuk mendapatkan pendidikan (Mikkola, Anne, 2005:12).

Studi tentang pembangunan dapat dianggap bermula dari paham klasik tentang EkonomiPolitik di abad ke delapan belas, namun akarnya dapat ditelusuri sampai pada hampir 25 abad yang lalu, ketika Plato dalam salah satu dialognya meletakkan dasar filosofis tentang hakekat Negara sebagai wadah bagi setiap warga negara untuk mencapai Eudaimonia, yaitu kebahagiaan sejati dan tertinggi, sedangkan Adam Smith yang di dalam buku The Wealth of Nations meletakkan dasar-dasar ekonomi pada zaman pembangunan sebagai suatu gerakan Internasional(Ndrah, 1990).

\section{Badan Usaha Milik Desa}

Dalam UU Nomor 32 tahun 2004 dan PP Nomor 72 tahun 2005 diamanatkan bahwa dalam meningkatknpendapata masyarakat dan desa, pemerintah desa dapa mendirikan Badan Usaha Milik Desa (BUMDes) sesuai dengan kebutuhan dan potensi desa. Dalam hal perencanaan dan pembentukannya, BUMDes dibangun atas prakarsa (inisiasi masyarakat), serta men-dasarkan pada prinsip-prinsip kooperatif, partisipatif dan emansipatif, dengan dua 
prinsip yang mendasari, yaitu member base dan self help. Hal ini penting mengingat bahwa profesionalime pengelolaan BUMDes benar-benar didasarkan pada kemauan (kesepakatan) masyarakat banyak (member base), serta kemampuan setiap anggota untuk mandiri dalam memenuhi kebutuhan dasarnya (self help), baik untuk kepentingan produksi (sebagai produsen) maupun konsumsi (sebagai konsumen) harus dilakukan secara professional dan mandiri, Rahardjo dan Ludigdo (2006, h. 84).

Seperti yang telah dikemukakan diatas bahwa berdirinya Badan Usaha Milik desa ini karena sudah diamanatkan bahwa dalam meningkatkan pendapatan masyarakat dan desa, pemerintah desa dapat mendirikan badan usaha milik desa. Pilar lembaga BUMDes ini merupakan institusi sosial-ekonomi desa yang betul-betul mampu sebagai lembaga komersial yang mampu berkompetisi ke luar desa. BUMDes sebagai institusi ekonomi rakyat lembaga komersial, pertama-tama berpihak kepada pemenuhan kebutuhan (produktif maupun konsumtif) masyarakat adalah melalui pelayanan distribusi penyediaan barang dan jasa. Hal ini diwujudkan dalam pengadaan kebutuhan masyarakat yang tidak memberatkan (seperti:harga lebih murah dan mudah mendapatkannya) dan menguntungkan. Dalam hal ini, BUMDes sebagai institusi Komersiil, tetap memperhatikan efisiensi serta efektifitas dalam kegiatan sector riil dan lembaga keuangan (berlaku sebagai LKM), Rahardjo dan Ludigdo (2006,h.84).

\section{Bank Desa}

Bank desa adalah lembaga keuangan pedesaan baru yang baru bertanggangjawab atas untung dan rugi bertujuan untuk melayani seperti contoh dalam melayani kemaritiman, daerah pedesaan dan masyarakat nelayan.

\section{Kemitraan dan Tata Kelola Pemerintahan (Collaborative Governance)}

Kontemporer ini pemerintah tidak hanya mengandalkan pada kapasitas internal yang dimiliki dalam penerapan sebuah kebijakan dan pelaksanaan program. Keterbatasan kemampuan, sumberdaya maupun jaringan yang menjadi faktor pendukung terlaksananya suatu program atau kebijakan, mendorong pemerintah untuk melakukan kerjasama dengan berbagai pihak, baik dengan sesama pemerintah, pihak swasta maupun masyarakat dan komunitas masyarakat sipil sehingga dapat terjalin kerjasama dalam mencapai tujuan program atau kebijakan. Secara umum dijelaskan bahwa collaborative governance (kemitraan dan tata kelola pemerintahan) merupakan sebuah proses didalamnya melibatkan berbagai stakeholder yang terikat untuk mengusung kepentingan masing-masing instansi dalam mencapai tujuan bersama.

Menurut Agustinus (2015) dalam definisi ini tidak dijelaskan secara terperinci jenis organisasi apa saja yang tergabung dalam proses tersebut. Hanya saja memang pada umumnya sebuah kerjasama antar organisasi menuju pada tujuan yang telah disepakati bersama dengan pengaktualisasian kapasitas masing- masing pihak. Sedangkan Ansell \& Gash (2007, p544-545) mendefinisikan collaborative governance sebagai berikut. "A Governing arrangement where one or more publik agencies directly engage non-stakeholders in a collective decision-making process that is formal, consensus-oriented and deliberative and that aims to make or implement publik policy or manage publik program or assests" (Ansell \& Gash, 2007, p544-545), Sebuah pengaturan yang mengatur satu atau lebih lembaga publik secara langsung terlibat dengan pemangku kepentingan non publik dalam proses pengambilan keputusan kolektif yang bersifat 
formal, berorientasi konsensus, dan musyawarah yang bertujuan untuk membuat atau mengimplementasikan kebijakan publik atau mengelola aset publik. Definisi tersebut diatas dapat dirumuskan beberapa kata kunci yang menekankan pada enam karakteristik, antara lain: 1) Forum tersebut diinisiasi atau dilaksanakan oleh lembaga publik maupun aktor-aktor dalam lembaga public, 2) Peserta di dalam forum tersebut juga termasuk aktor non public, 3) Peserta terlibat secara langsung dalam pembuatan dan pengambilan keputusan dan keputusan tidak harus merujuk pada aktor-aktor public, 4) Forum terorganisir secara formal dan pertemuan diadakan secara bersama-sama, 5).Forum bertujuan untuk membuat keputusan atas kesepakatan bersama, dengan kata lain forum ini berorientasi pada consensus, 6).Kolaborasi berfokus pada kebijakan publik dan manajemen publik.

Definisi ini dimaknai bahwa forum tersebut ada pada keterikatan formal sehingga disebutkan hanya berkisar pada kerjasama antara lembaga publik, aktor publik dengan aktor non publik. Terdapat tipe kontemporer dalam praktek collaborative governance yaitu penta helix collaboration yang merupakan kerjasama antar lima pihak yaitu pemerintah, swasta, akademisi, masyarakat dan media massa. Menurut Muhyi, Chan, Sukoco, \& Herawaty (2017) penta helix collaboration atau quintuple helix collaboration yang ditambahkan oleh lingkungan semakin lengkap dalam kelima elemen ini bersinergi untuk memberi dampak pada pengembangan di area tersebut. Setiap upaya untuk menghubungkan layanan publik yang baik dengan investasi yang dilakukan di wilayah ini mungkin bukan hal yang baru. Pelayanan publik yang baik harus dilaksanakan oleh pemerintah sebagai pelayan publik ditujukan untuk kebutuhan masyarakat belum berjalan dengan baik. Sementara itu, media adalah pemangku kepentingan yang memiliki lebih banyak informasi untuk mengembangkan dan memainkan peran dalam mempromosikan inovasi. Model penta helix collaboration menunjukkan bahwa kehadiran inovasi dalam ilmu pengetahuan dan teknologi serta promosi, kegiatan pelayanan baik dalam bentuk peraturan atau legislasi yang dapat dibawa ke dalam perubahan baru sehingga model ini menjelaskan bahwa implementasi inovasi sesuatu tentang kemitraan lima pihak secara berkelanjutan akan memiliki dampak positif pada pengembangan masyarakat secara keseluruhannya.

Tentunya pembahasan mengenai collaborative governance tidak bisa terlepas dari pembahasan mengenai adanya konsep partnership (rekan kerja). Salah satu perwujudan konkret dari collaborative governance pada saat ini adalah adanya public private partnership. Menurut Etzkowitz \& Leydesdorff (2000) konsep partnership atau kemitraan antara pemerintah dengan swasta sudah menjadi hal yang umum dalam melaksanakan suatu pembangunan dalam rangka penyelengaraan pelayanan publik. Berbeda dengan masa lampau, dalam hal penyediaan infrastruktur dan pelayanan publik hanya menjadi tanggung jawab pemerintah. Saat ini sektor swasta dan civil society mesti ikut terlibat didalam penyelengaraan pelayanan publik. Dengan konsep kemitraan maka segala bentuk dukungan dapat dilengkapi dari sektor publik dan sektor swasta dalam upaya membangun komunitas. Seperti halnya pengetahuan umum bahwa masing- masing sektor, baik pemerintah, swasta maupun lembaga non-profit memiliki keterbatasan tertentu dan kapasitasnya yang berbeda-beda dalam beberapa bidang. Untuk itu kemitraan menjadi jawaban atas permasalahan tersebut, pihak-pihak tersebut menyadari bahwa membangun sebuah entitas dibutuhkan berbagai sumberdaya dan keahlian yang saling mendukung. Dengan kemitraan maka masalah bersama dapat diatasi melalui kesepakatan seluruh pemangku kepentingan (Irawati, 2007).

Salah satu bentuk dalam konsep penyelenggaraan pemerintahan atau governance yakni disebut konsep collaborative governance atau penyelenggaraan pemerintahan yang kolaboratif. Menurut pendapat Ansell dan Grash "Collaborative governance is therefore a type 
of governance in which public and private actor work collectively in distinctive way, using particular processes, to establish laws and rules for the provision of public goods" (Ansell dan Gash, 2007:545).

Collaborative Governance dapat dikatakan sebagai salah satu dari tipe governance. Konsep ini menyatakan akan pentingnya suatu kondisi dimana aktor publik dan aktor privat (bisnis) bekerja sama dengan cara dan proses terentu yang nantinya akan menghasilkan produk hukum, aturan, dan kebijakan yang tepat untuk publik atau,masyarakat. Konsep ini menunujukkan bahwa dalam penyelenggaraan pemerintahan. Aktor publik yaitu pemerintah dan aktor privat yaitu organisasi bisnis atau perusahaan bukanlah suatau yang terpisah dan bekerja secara sendiri-sendiri melainkan bekerja bersama demi kepentingan masyarakat.

Kolaborasi dipahami sebagai kerjasama antar aktor, antar organisasi atau antar institusi dalam rangka pencapain tujuan yang tidak bisa dicapai atau dilakukan secara independent. Dalam bahasa Indonesia, istilah kerjasama dan kolaborasi masih digunakan secara bergantian dan belum ada upaya untuk menunjukkan perbedaan dan kedalaman makna dari istilah tersebut.Secara definisi, para ahli mendefinisikan collaborative governance dalam beberapa makna yang ide utamanya sama, yakni adanya kolaborasi antara sektor publik dan nonpublic atau privat dalam penyelenggaraan pemerintahan atau governance. Ansell dan Gash (2007:546) mendefinisikan collaborative governance sebagai serangkain pengaturan dimana satu atau lebih lembaga publik yang melibatkan secara langsung stakeholder non-state di dalam proses pembuatan kebijakan yang bersifat formal, berorientasi consensus dan deliberative yang bertujuan untuk membuat atau mengimplementasikan kebijakan publik atau mengatur program atau aset. Disamping pendapat tersebut, pendapat lain mengenai collaborative governance dikemukakan Agranoff dan McGuire dalam Chang (2009:76-77) yang menyatakan sebagai berikut:

Secara khusus, collaborative gvernance telah menempatkan banyak penekanan pada kolaborasi horisontal sukarela dan hubungan horizontal anatara partisipan multi sektoral, karena tuntutan dari klien sering melampaui kapasitas dan peran organisasi publik tunggal, dan membutuhkan interaksi di antara berbagai organisasi yang terkait dan terlibat dalam kegiatan publik. kolaborasi diperlukan untuk memungkinkan governance menjadi terstruktur sehingga efektif memenuhi meningkatnya permintaan yang timbul dari pengelolaan lintas pemerintah, organisasi, dan batas sektoral

Berdasarkan pada pendefinisian oleh dua ahli tersebut, sebenarnya telah mendefinisakan collaborative governance dalam gagasan yang sama. Akan tetapi pada penjelasan Ansell dan Gash dapat dlihat bahwa aspek kolaborasi penyelenggara pemerintah lebih pada aspek perumusan dan impletasi kebijakan publik atau program dari lembaga publik, dalam hal ini yakni pemerintah. Selain itu, dalam praktiknya kolaboasi penyelenggaraan pemerintah haruslah menjunjung tinggi nilai deliberatifatau musyawarah dan konsensus antar tiap aktor atau stakeholder ya terlbat dalam kolaborasi tersebut.

Sedangkan pada gagasan Agranoff dan McGuire menunjukkan bahwa collaborative governance atau kolaborasi penyeggaran pemerintahan dalam lingkup yang lebih general yakni penyelenggraan pemerintahan secara keseluruhan. Collaborative governance dalam hal ini lebih menitik beratkan pada aspek sukarela dalam praktik kolaborasi. Aspek kesukarelaan tersebut diharapkan setiap aktor yang terlibat dalam kolaborasi bekerja secara optimal untuk tercapainya tujuan dalam kolaborasi. Sehingga program atau kebijakan yang yang dilaksanakan akan terksana lebih efektif karna melibatkan relasi oganisasi atau institusi. 


\section{METODE PENELITIAN}

\section{Objek Penelitian}

Objek penelitian ini adalah inovasi mahasiswa pemanfaatan Badan usaha milik desa dalam peningkatan Ekonomi pembangunan berkelanjutan dengan membentuk bank desa. Adapun strategi yang digunakan dalam mengimplementasikan ini yaitu bersinergi antar pihak dengan menggunakan pendekatan Collaborative Governance.

\section{Jenis Penelitian}

Penelitian ini berjenis deskriptif dengan pendekatan kualitatif. Karena penelitian ini berusaha untuk mengungkapkan suatu fakta atau peristiwa sebagaimana adanya, dan memberikan gambaran objektif tentang keadaan atau permasalahan yang dihadapi. Adapun penelitian berjenis deskriptif ini untuk memuat gambaran atau lukisan secara sistematik, faktual dan akurat mengenai fakta-fakta, sifat-sifat serta hubungan antar fenomena yang diselidiki. Penelitian ini berjenis deskriptif dengan pendekatan kualitatif. Karena penelitian ini berusaha untuk mengungkapkan suatu fakta atau peristiwa sebagaimana adanya, dan memberikan gambaran objektif tentang keadaan atau permasalahan yang dihadapi. Adapun penelitian berjenis deskriptif ini untuk memuat gambaran atau lukisan secara sistematik, faktual dan akurat mengenai fakta-fakta, sifat-sifat serta hubungan antar fenomena yang diselidiki.

\section{Teknik dan Alat Pengumpulan Data}

Menurut Nazir (2003:221), pengumpulan data adalah proses pengadaan data primer untuk keperluan penelitian. Pengumpulan data dapat pula diartikan sebagai cara peneliti menentukan metode setepat-tepatnya untuk memperoleh data. Untuk mengumpulkan data yang diperlukan dalam penelitian ini, Peneliti menggunakan teknik penggumpulan data : a) Studi Pustaka; pengumpulan data dengan melakukan bedah pustaka, mengambil data teoritis untuk membangun landasan teori yang kuat dan pendukung analisis yang dipakai. Teknik ini dilakukan dengan mempelajari literatur-literatur, catatan-catatan kuliah dan dokumen yang relevan dengan masalah yang diteliti.

\section{Sumber Data}

Data primer; Data primer merupakan data yang menjadi bahan utama dalam melakukan penelitian. Sejauh ini, peneliti hanya mampu menyajikan kajian ilmiah dari jurnal internasional terjemahan Analysis on Sustainable Development Management Model of Village Banks - Based on Bayan Rongxing Village Bank in Heilongjiang Province. Data Sekunder; Data sekunder merupakan data pendukung bahan utama penelitian ini. Data sekunder ini diperoleh dari informasi baik dari media cetak maupun media online.

\section{Teknik Analisis Data}

Analisis data yang dipergunakan dalam penelitian ini adalah analisis secara kualitatif dengan menggunakan model analisis interaktif. Miles dalam Sugiyono (2008:246), mengemukakan bahwa aktivitas dalam analisis data kualitatif dilakukan secara interaktif dan 
berlangsung secara terus-menerus sampai tuntas, hingga datanya sudah jenuh. Aktifitas dalam analisis data, yaitu a) Reduksi Data; Merupakan bagian dari analisis yang mempertegas, memperpendek, membuat fokus, membuang hal-hal yang tidak penting dan mengatur data sedemikian rupa sehingga dapat membuat kesimpulan akhir, b) Sajian Data; Merupakan suatu rakitan organisasi informasi, deskriptif dalam bentuk narasi yang memungkinkan kesimpulan riset dapat dilakukan. Sajian data harus mengacu pada rumusan masalah sehingga dapat menjawab permasalahan-permasalahan yang diteliti, c) Penarikan Kesimpulan; Dari awal pengumpulan data, peneliti sudah harus memahami arti dari berbagai hal yang ia temui dengan melakukan pencatatan peraturan-peraturan, pola-pola, pernyataan-pernyataan, arahan, sebab akibat dan berbagai proporsi. Kesimpulan perlu diverifikasi agar penelitian yang dilakukan benar dan bisa dipertahankan, d) Keabsahan DataKredibilitas penelitian kualitatif ini dilakukan melalui trianggulasi. Trianggulasi merupakan teknik penarikan keabsahan data yang memanfaatkan.

\section{Sistematika Penulisan}

Sistematika pembahasan di dalam penyusunan karya tulis ilmiah in dibagi kedalam tiga bagian yaitu bagian awal, bagian inti dan bagian akhir. Bagian awal terdiri dari halaman judul, halaman pengesahan, halaman orisinalitas karya tulis, kata pengantar, abstrak, daftar isi, daftar bagan. Bagian tengah berisi untaian penelitian mulai dari bagian pendahuluan sampai bagian penutup yang tertuang dalam bentuk bab-bab sebagai sebuah satu kesatuan. Pada karya tulis ilmiah ini, peneliti menuangkan hasil penelitian ke dalam empat bab. Pada tiap-tiap bab terdapat sub-bab yang menjelaskan pokok bahasan dari bab yang bersangkutan.

Artikel ilmiah ini merupakan penelitian kepustakaan dengan sumber data primer berupa Jurnal Internasional karya Ansell \& Gash. Collaborative Governance in Theory and Practice, buku Kebijakan Publik dan Pemerintahan Kolaboratif: Isu-Isu Kontemporer dan buku Sistem Pendidikan Finlandia (Finnish Lessons) karya Sahlberg. Adapaun bagian terakhir dari bagian inti tulisan ilmiah ini adalah memuat kesimpulan, saran-saran dan atau rekomendasi.

\section{PEMBAHASAN}

\section{Pembangunan Bank Desa}

Kesejahteraan warga desa sebagai bagian terkecil dari suatu pemerintahan masih rendah. Desa sebagai bagian suatu susunan pemerintahan yang berada di tingkat paling bawah, maka penting juga memperhatikan kondisi ekonomi dan kesejahteraan warga desa. Pemerintah harus hadir sampai ke desa memastikan warganya mendapat perlindungan ekonomi, salah satunya lewat inovasi Bank Desa.

Bank Desa dapat dijadikan alternatif dikalangan masyarakat desa yang banyak terjerat rentenir. kurangnya masyarakat desa mendapat bantuan ketika sulit, sulitnya mencari modal ketika akan memulai usaha maupun memperbesar usaha. Perlu diketahui juga kalau desa saat ini sudah menjadi pasar, perputaran uang yang luar biasa juga terjadi didesa karena menjadi arena perdagangan. Karena itu harus mulai digerakan dan disiapkan peraturan untuk menjalankan Bank Desa. Berdasarkan survei World Bank tahun 2013 menemukan sebanyak $60 \%$ warga Indonesia cenderung atau biasa meminjam uang, tetapi hanya $17 \%$ yang mengakses pinjaman di bank dan $43 \%$ sisanya mengutang di layanan informal. Hal ini 
menunjukkan bahwa akses masyarakat ke bank sangat rendah, terutama yang tinggal di pedesaan.

Ide bank desa ternyata sejalan juga dengan pemikiran ahli ekonomi Indonesia, Hary Tanoe. Bagi Hary Tanoe, bank desa bisa memberi akses bagi masyarakat untuk mendapat modal yang mudah dan murah. Mudah mendapatnya dan murah bunganya, alias rendah. Lewta bank desa nantinya bisa dibuat kebijakan untuk manajemen pengolahan uang di pedesaan. Tujuan akhirnya adalah menciptakan sebanyak-banyaknya masyarakat supaya berkembang dan bisa mengembangkan usahanya sehingga menciptakan lapangan-lapangan kerja baru. Selanjutnya digerakkan supaya masyarakat pedesaan menaruh uangnya di bank desa, bukan di bank lain, uang yang terhimpun dikelola dan diberdayakan bersama dari desa untuk desa.

Ditengah mahalnya bahan pokok dan sulitnya mencari pinjaman maka Bank Desa bisa menjadi andalan dalam menghadapi permasalahan ekonomi warga desa yangmana manfaat dari bank desa nantinya juga sangat besar dan dapat memberikan keuntungan bagi semua pihak terutama warga desa itu sendiri, baik petani, nelayan maupun pedagang-pedagang kecil.

\section{Strategi Bank Desa}

Secara umum dijelaskan bahwa collaborative governance (kemitraan dan tata kelola pemerintahan) merupakan sebuah proses didalamnya melibatkan berbagai stakeholder yang terikat untuk mengusung kepentingan masing-masing instansi dalam mencapai tujuan bersama. Menurut Agustinus (2015) dalam definisi ini tidak dijelaskan secara terperinci jenis organisasi apa saja yang tergabung dalam proses tersebut. Hanya saja memang pada umumnya sebuah kerjasama antar organisasi menuju pada tujuan yang telah disepakati bersama dengan pengaktualisasian kapasitas masing-masing pihak.

Badan Usaha Milik desa ini karena sudah diamanatkan bahwa dalam meningkatkan pendapatan masyarakat dan desa, pemerintah desa dapat mendirikan badan usaha milik desa. Pilar lembaga BUMDes ini merupakan institusi sosial-ekonomi desa yang betul-betul mampu sebagai lembaga komersial yang mampu berkompetisi ke luar desa. BUMDes sebagai institusi ekonomi rakyat lembaga komersial, pertama-tama berpihak kepada pemenuhan kebutuhan (produktif maupun konsumtif) masyarakat adalah melalui pelayanan distribusi penyediaan barang dan jasa. Hal ini diwujudkan dalam pengadaan kebutuhan masyarakat yang tidak memberatkan (seperti:harga lebih murah dan mudah mendapatkannya) dan menguntungkan. Dalam hal ini, BUMDes sebagai institusi Komersiil, tetap memperhatikan efisiensi serta efektifitas dalam kegiatan sector riil dan lembaga keuangan (berlaku sebagai LKM), Rahardjo dan Ludigdo (2006,h.84).

Pembangunan-berkelanjutan sedang dalam proses mengejar kelangsungan hidup sendiri dan pembangunan berkelanjutan. Kita harus mengembangkan dan memanfaatkan sumber daya sepenuhnya. Tidak hanya Secara umum, model manajemen bank desa sama dengan model bank komersial. Namun, berdasarkan situasi yang berbeda di masingmasing daerah, model pengelolaan bank desa berbeda. bank desa memiliki skala operasi yang kecil dan bentuk organisasi yang sederhana. Bank desa didirikan di daerah pedesaan,

Untuk membangun lingkungan keuangan yang baik, pertama Bank Desa harus memperhatikan penerapan konstruksi lingkungan, dengan struktur tata kelola yang baik dan 
mekanisme insentif. Faktor-faktor yang tidak pasti dan tidak sempurna masih ada di daerah pedesaan, dukungan kebijakan pemerintah dan langkah-langkah pengaturan keuangan memainkan peran "baling-baling angin" dalam pengembangan Bank Desa, yang akan membuatnya berkembang cepat (Zhang, 2010). Bank Desa harus menjaga hubungan kerja sama jangka panjang yang baik dengan pemerintah.

Pemerintah dapat menjadi pemegang saham bank desa ini untuk mendukung dan membayar setoran rasio pajak. Proses ini tidak hanya menekan situasi bank-bank komersial dengan dana, tetapi tidak mengembangkan bisnis di daerah pedesaan, sementara bank desa memperluas uasaha perikanan tetapi menderita dari status bahwa mereka tidak memiliki uang. Ambil reputasi pemerintah sebagai merek, ubah gagasan publik bahwa bank desa adalah bank pribadi. Ini adalah pendekatan yang baik bagi Bank Desa dimana Pemerintah memainkan peran penting, yang tanggung jawabnya adalah untuk membentuk kerja sama aktif antara Bank Desa dan pemerintahan.

Bank desa menggunakan mode pertama, ada masalah bahwa bank asli enggan menjadi agen untuk menduduki modal bank induk. Saat ini, Bank Desa Bayan Rongxing harus meningkatkan peralatan perangkat keras, perekrutan tenaga teknis, menentukan pencegahan risiko kredit, kemudian harus berkoordinasi dengan bank asli untuk mengambil bagian dalam sistem pembayaran dan membayar sejumlah biaya keagenan.

Bank desa membawa mode manajemen yang sukses dari bank desa lainnya, menerapkannya untuk meningkatkan model manajemen bank desa dan mengeksplorasi model yang sesuai untuk operasi mereka sendiri. Bank desa dapat mencari pembangunan berkelanjutan dalam proses reformasi dan membuat kemajuan dalam pembangunan berkelanjutan. Tujuan bank desa adalah untuk mendukung pengembangan ekonomi pedesaan

\section{REKOMENDASI DAN KEBIJAKAN}

\section{Rekomendasi}

Untuk membangun lingkungan keuangan yang baik, pertama Bank Desa harus memperhatikan penerapan konstruksi lingkungan, dengan struktur tata kelola yang baik dan mekanisme insentif. Faktor-faktor yang tidak pasti dan tidak sempurna masih ada di daerah pedesaan, dukungan kebijakan pemerintah dan langkah-langkah pengaturan keuangan memainkan peran "baling-baling angin" dalam pengembangan Bank, yang akan membuatnya berkembang cepat. Bank Desa harus menjaga hubungan kerja sama jangka panjang yang baik antara pemerintah.dengan pendekatan collaborative governance

\section{Kebijakan}

Bank desa diharapkan harus memiliki kemampuan untuk bergabung dengan sistem pembayaran dan mengembangkan revolusi industry 4.0 dngan membuka aplikasi kartu bank dengan sendirinya. Inovasi itu penting dalam mode operasi bank desa. Perlu mempertimbangkan tujuan bank desa dan posisi pasar mereka, tetapi juga untuk mempertahankan pertumbuhan laba di bidang persaingan yang ada dan perluasan lingkungan bisnis di masa depan. 


\section{DAFTAR PUSTAKA}

Agustinus, S. (2015). Kebijakan Publik dan Pemerintahan Kolaboratif: Isu-Isu Kontemporer (Gava Media). Yogyakarta.

Ansell, C., \& Gash, A. (2007). Collaborative governance in theory and practice. Journal of Public Administration Research and Theory, 18(4), 543-571.

Etzkowitz, H., \& Leydesdorff, L. (2000). The Dynamics of Innovation: From National Sistems and "Mode 2" Toa Triple Helix of University-Industri-Government Relations. Research Policy, 29, 109-123.

Irawati, D. (2007). Understanding The Triple Helix Model from The Perspective of the Developing Country: A Demand or A Challange for Indonesian Case Study. East, (5829), $0-15$.

Muhyi, H. A., Chan, A., Sukoco, I., \& Herawaty, T. (2017). The Penta Helix Collaboration Model in Developing Centers of Flagship Industry in Bandung City. Review of Integrative Business and Economics Research, 6(1), 412-417.

Ndrah, T. (1990). Pembangunan Masyarakat. Jakarta: Rineka Cipta.

Shuang, Wang;Wang, Ji, Heng;Li, Ub., \& Yu, X. (2015). Analysis on Sustainable Development Management Model of Village Banks - Based on Bayan Rongxing Village Bank in Heilongjiang Province. Jurnal of Northest Agricurlural University, 22 No. 4, 8.

Shuang, W., Ji-heng, W., Bing, L., \& Xiao-wen, Y. (2015). Analysis on Sustainable Development Management Model of Village Banks - Based on Bayan Rongxing Village Bank in Heilongjiang Province. Journal of Northeast Agricultural University, 22(4), 75-82. https://doi.org/10.1016/S1006-8104(16)30022-8 